\title{
Development of the Medical Intensive Care Unit Shift Report Communication Scale as a measure of nurses' perception of communication
}

This article was published in the following Dove Press journal:

Nursing: Research and Reviews

13 April 2013

Number of times this article has been viewed

\author{
David James' \\ Angela Jukkala ${ }^{2}$ \\ Andres Azuero ${ }^{2}$ \\ Pamela Autrey ${ }^{3}$ \\ Lynne Vining ${ }^{4}$ \\ Rebecca Miltner ${ }^{2}$ \\ 'Center for Nursing Excellence, \\ University of Alabama at Birmingham \\ Hospital, ${ }^{2}$ School of Nursing, \\ University of Alabama at Birmingham, \\ ${ }^{3}$ Nursing Administration, University \\ of Alabama at Birmingham Hospital, \\ ${ }^{4}$ Medical Intensive Care Unit, \\ University of Alabama at Birmingham \\ Hospital, Birmingham, Alabama, USA
}

Correspondence: Angela Jukkala School of Nursing, Community Health, Outcomes, and Systems, University of Alabama at Birmingham,

1720 2nd Ave South, NB 312,

Birmingham, AL 35294-1210, USA

$\mathrm{Tel}+\mathrm{I} 2059966136$

Fax +I 2059967177

Email jukkalaa@uab.edu
Objective: Evidence documenting the negative impact of poor communication on patient safety during intra-hospital transfer is prevalent and attributed to $80 \%$ of serious medical errors. An event particularly vulnerable to communication error is the patient "handoff." One of the more common handoffs occurring in health care settings is the report provided between nurses at the change of shift. The objective of this article is to report the process used to develop and examine the reliability and validity of a Medical Intensive Care Unit (MICU) Shift Report Communication Scale to measure nurses' perception of the quality and quantity of communication during shift report

Design and participants: This was a scale development and descriptive study undertaken at the Medical Intensive Care Unit within an Academic Health Center. Forty-three medical intensive care nurses took part.

Results: An exploratory factor analysis revealed three domains: communication openness, quality of information, and shift report. Medical Intensive Care Unit Shift Report Communication Scale scores ranged from 12 to $27($ mean $=18.78$; standard deviation $=3.28)$. Perception of communication did not vary between nurses based on years of nursing experience or age. Scale reliability was good (Cronbach's alpha $=0.079$ ). Nurses were likely to have had a positive perception of the openness of communication on the unit. However, they had a less favorable perception of peer ability to fully understand information shared during shift report and identified as a common problem the frequent need to review the chart to verify reported information.

Conclusion: The MICU Shift Report Communication Scale may be used to provide useful information to support health care organizations and nurse leaders in the evaluation of nurse communication during shift report. Initial testing indicates that the MICU Shift Report Communication Scale is easy to use; however, additional testing with larger groups of nurses is needed.

Keywords: medical error, patient handoff, patient safety

\section{Introduction}

Evidence documenting the negative impact of poor communication on patient safety during intra-hospital transfer is prevalent. ${ }^{1}$ According to The Joint Commission (an acknowledged international authority on health care quality and safety), poor communication can be attributed to $80 \%$ of serious adverse medical errors. ${ }^{2}$ An event particularly vulnerable to communication error is the patient "handoff." One of the more common handoffs occurring in health care settings is the report provided between nurses at the change of shift. ${ }^{3}$ The primary function of the nursing shift report is to communicate care status, current treatments, and any expected or recent changes to 
facilitate continuity of care between nurses as responsibility for care is transferred. However, during the timeframe of report, other activities may occur as well, such as education relative to clinical practice and socialization. ${ }^{4,5}$ The format for shift report handover can be written or verbal, at the bedside or in a report room, extensive in detail, exhaustive in time, or a few short sentences. Due to this lack of structure, there may be significant variability in the quality and quantity of the vital patient information exchanged. ${ }^{6,7}$

Although the health care system has been designed to require frequent handoffs between nurses, minimal attention has been directed to the development systems and processes to guide effective communication during the shift report between nurses. ${ }^{8,9}$ In response to the need to improve communication between all members of the health care team, The Joint Commission strongly advocates for the development and assessment of a standardized approach to handoff communication as a national patient safety goal. ${ }^{10,11}$ The definition of "handoff" is not clearly delineated in the literature. ${ }^{12}$ However, The Joint Commission defines "handoff" as "a transfer and acceptance of patient care responsibility achieved through effective communication."13 Standardized handoff communication is further defined as "a process in which information about patient/client/resident care is communicated in a consistent manner from one healthcare provider to another." 13

Prior research has found standardization of communication to be an effective intervention to improve the exchange of vital patient information between health care professionals. ${ }^{2,8}$ Serving not only as a guide for communication in regard to content and clarity, standardized communication tools have also been found to bridge differences in communication style between health care professionals ${ }^{2}$ and facilitate the return to shift report following interruptions. ${ }^{9}$ However, little is known about the impact of these standardized tools on nurse perception of the quality and quantity of communication. It is possible that implementation of standardized tools to improve communication may actually decrease the quality of information exchanged if the handoff does not provide for a shared cognitive picture, creates tension between giving and listening to shift report, and fragments communication. ${ }^{14}$

\section{Background}

The complexity of providing nursing care in critical care environments, such as a medical intensive care unit (MICU), often necessitates that nurses simultaneously manage multiple competing priorities and distractions. Shift report is no exception, as nurses strive to provide an accurate and complete report amid the hectic environment within a constrained timeframe. On the level of the individual nurse, shift report can be distorted by stress, fatigue, imperfect information processing, flawed decision-making, eagerness to complete the shift, and possible relationship issues between the individuals involved in the handoff., ${ }^{9,15}$ The critical care environment may also affect shift report due to interruptions from alarms, staff, patients, families, and phone calls. ${ }^{8}$ Thus, the complexity of the MICU practice environment along with limitations inherent in human performance ensure mistakes in communication will occur, even when nurses are knowledgeable, skilled, and highly motivated. ${ }^{2}$ Inconsistencies in the handoff process are a result of communication errors ${ }^{16}$ that lead to inappropriate or delay in treatment, extended length of stay, and increased costs. ${ }^{17-19}$

Standardized approaches to patient handoff have been implemented in many health care settings. One wellknown approach is "situation, background, assessment, recommendation" (SBAR) (Table 1), which provides a framework for communication between health care professionals for critical conversations requiring immediate attention. ${ }^{20}$ However, SBAR is not detailed enough to determine specific content for shift report communication, as it provides only topic standardization (eg, situation) and a starting point for content standardization (eg, provide a succinct report of the situation). ${ }^{12}$ Though gaining momentum as a best practice to guide urgent communication, ${ }^{21}$ evidence to support improved patient safety and/or outcomes related to implementation of SBAR communication is anecdotal. ${ }^{8}$

A vital step in the development of an effective standardized communication tool is the involvement of front-line staff to ensure the resulting tool is consistent with the natural flow of shift report and contains all critical information needed to care for patients within the care unit or microsystem. ${ }^{8,9,22}$ A rapidly growing approach to improving health care quality and safety is application of the "microsystem framework,"23 which was developed for use at the unit level and contrasts with the traditional approach to quality improvement

Table I "Situation, background, assessment, recommendation" approach for communication between health care professionals for critical conversations requiring immediate attention ${ }^{20}$

\begin{tabular}{ll}
\hline Component & Report information \\
\hline Situation & Describe succinctly patient's condition \\
Background & Provide brief, relevant patient history \\
Assessment & Your interpretation of current findings \\
Recommendation & Your recommendation for action and \\
& the timeframe in which this action \\
& needs to occur \\
\hline
\end{tabular}


activities being generated from organizational leaders. The microsystem framework guides the collection of information, describing the purpose of the microsystem (care unit), patients served on the unit, health care professionals working within a unit, and patterns and processes of care delivered. As health care system quality, safety, and cost outcomes are generated from care delivered within microsystems, overall health care improvement is dependent on improvement at the point of care.

The purpose of this article is to report the process used to develop and examine the reliability and validity of the MICU Shift Report Communication Scale as a measure of nurses' perception of the quality and quantity of nurse communication during shift report.

\section{Methods}

\section{Study design and setting}

A descriptive, comparative, pre/post design was utilized. The development and initial testing of the MICU Shift Report Communication Scale as an instrument to measure nurse perceptions on the quality and quantity of communication during shift report was part of a larger unit-based quality improvement initiative. ${ }^{24}$ The study took place in a 25 -bed MICU within a large academic health center in the southern USA. The average daily census was 24 , with an average length of stay of 14.67 days. There were 90 registered nurses working within the MICU, most of whom worked full-time providing care in 12-hour shifts. Inclusion criteria were being a registered nurse in the MICU and being scheduled to work three shifts during the initial 2 weeks of the study. Exclusion criteria were being a nurse in the "float pool" or not working for three scheduled shifts during the study period. The final number of registered nurses eligible to participate in the study was 70 .

\section{Revision of the Nurse-Nurse Collaboration Scale communication subscale}

Dougherty and Larson developed the Nurse-Nurse Collaboration Scale as a measure of collaboration between nurses working in diverse intensive care unit environments (cardiothoracic, surgical, neurological, and coronary care). ${ }^{25}$ While other tools to measure communication and/or collaboration were considered for our study, ${ }^{26-29}$ specificity of communication between nurses within an intensive care unit environment was the determining factor in selection of the Nurse-Nurse Collaboration Scale. Within the Nurse-Nurse Collaboration Scale, the construct of communication was measured using an eight-item communication scale, with a Cronbach's alpha of $0.66 .{ }^{30}$ However, the instrument was not specific to the MICU environment and did not gather information specific to shift report. For this reason, the communication subscale was revised with permission to be specific to shift report and the MICU environment. Following careful review by the researchers and members of the lead team, one item was deleted ("I can count the number of times I have received accurate information from nurses on this unit"), and two items were added to gather information specific to nurse communication during shift report ("The change of shift report I receive prepares me to care for my patient" and "The change of shift report I receive on my patients helps me do my job well"). Each item on the MICU Shift Report Communication Scale was measured on a Likert scale with the anchors of "Strongly agree" (one point), "Agree" (two points), "Disagree" (three points), and "Strongly disagree" (four points). Total scores for the nine-item MICU Shift Report Communication Scale can range from 9 to 36, with lower scores indicating a more favorable overall perception of the quality and quantity of communication between nurses in the MICU. Other items were either substituted or added.

A panel of three nursing and health systems administration nurse faculty members reviewed the revised MICU Shift Report Communication Scale for content, readability, and ease of use. In the end, the panel made no recommendations concerning content or readability.

\section{Procedures}

Procedures for the study were reviewed and approved by the University of Alabama at Birmingham's institutional review board. MICU staff nurses were informed that a standardized tool (the MICU Communication Tool) ${ }^{24}$ to guide communication during shift report was being developed and pilot tested by the MICU lead team in direct response to MICU staff nurse identification of poor communication during shift report. Nurses were asked to evaluate this new communication tool using the MICU Shift Report Communication Scale. Random numeric identifiers assigned to each nurse were used to link baseline and follow-up responses and to support anonymity. Completed and returned surveys implied consent.

\section{Data analysis}

Item analysis was conducted using classical test theory-based statistics. The MICU Shift Report Communication Scale item responses were tallied and corrected and item-total test score correlations were estimated. Cronbach's alpha was used to estimate a lower bound for reliability. Pearson's correlations 
were used to index linear associations. Scale development involved several steps, including revision and new item development, expert review, exploratory factor analysis, and reliability testing. Independent $t$-tests were used for mean value comparisons; the nominal type 1 error rate was set at 0.05. Participants' MICU Shift Report Communication Scale and subscale scores were further examined by age $(<30$ and $\geq 30$ ) and MICU experience ( $<1$ year and $\geq 1$ year). All analyses were conducted using Predictive Analytics Software Statistics (v 17; IBM, Armonk, NY, USA).

\section{Results}

\section{Sample}

The initial testing of the MICU Shift Report Communication Scale was with registered nurses who completed the instrument at baseline ( $\mathrm{N}=43 ; 60 \%)$. Mean participant age was 32.7 years (standard deviation $[\mathrm{SD}]=9.48$; range: 23-57 years). The majority of participants were female $(\mathrm{n}=34 ; 81.0 \%)$. Participant education preparation varied, with five (11.9\%) having an associate degree in nursing, $33(78.6 \%)$ having a baccalaureate degree in nursing, and four $(9.5 \%)$ with qualifications at master's level or higher. Average length of time providing care within the MICU was 3 years and 6 months ( $\mathrm{SD}=2$ years and 8 months; range: $0-22$ years). Twelve nurses (28.6\%) had worked in the MICU for $<1$ year and/or had $<1$ year of experience. Most nurses $(\mathrm{n}=31 ; 73.8 \%)$ had not worked in an intensive care setting prior to their current position in the MICU.

\section{Item analysis}

No missing responses were detected among 42 participants, and these were used to test the MICU Shift Report Communication Scale. A principal-factor oblimin-rotated exploratory factor analysis using squared multiple correlations as initial communality estimates, and constrained to explain at least $95 \%$ of the estimated common variance, resulted in three factors, all of which had eigenvalues of $\geq 1$. Inter-factor correlations ranged from 0.18 to 0.33 . The three factors appeared well defined: four items related to openness of communication among nurses loaded high on the first factor, two items related to quality of the information exchanged between nurses loaded high on the second factor, and the remaining three items related to shift reporting loaded high on the third factor. Thus, the MICU Shift Report Communication Scale subscales were labeled "open communication," "quality of information," and "shift report," corresponding to Factor 1, 2, and 3, respectively. Factor loadings and final assignment of items to their respective domains are shown in Table 2.
Table 2 Principal factor analysis oblimin-rotated factor pattern $(n=42)$

\begin{tabular}{|c|c|c|c|}
\hline $\begin{array}{l}\text { Medical Intensive Care } \\
\text { Unit (MICU) Shift Report } \\
\text { Scale item }\end{array}$ & Factor I & Factor 2 & Factor 3 \\
\hline \multicolumn{4}{|l|}{ Open communication } \\
\hline $\begin{array}{l}\text { I find it enjoyable to talk with } \\
\text { other nurses on this unit }\end{array}$ & 0.62 & & 0.44 \\
\hline $\begin{array}{l}\text { It is easy to ask advice } \\
\text { from nurses on this unit }\end{array}$ & 0.78 & & \\
\hline $\begin{array}{l}\text { It is easy for me to talk openly } \\
\text { with nurses in the MICU }\end{array}$ & 0.83 & & \\
\hline $\begin{array}{l}\text { Communication between } \\
\text { nurses is very open }\end{array}$ & 0.70 & & \\
\hline $\begin{array}{l}\text { Quality of information } \\
\text { exchanged }\end{array}$ & & & \\
\hline $\begin{array}{l}\text { The accuracy of information } \\
\text { passed among nurses on this } \\
\text { unit leaves much to be desired }\end{array}$ & & 0.85 & \\
\hline $\begin{array}{l}\text { I feel that certain nurses do } \\
\text { not completely understand } \\
\text { the information they receive }\end{array}$ & & 0.78 & \\
\hline Shift report & & & \\
\hline $\begin{array}{l}\text { The change of shift report I } \\
\text { receive prepares me to care } \\
\text { for my patient }\end{array}$ & & & 0.88 \\
\hline $\begin{array}{l}\text { It is often necessary for me } \\
\text { to go back and check the } \\
\text { accuracy of information }\end{array}$ & & & 0.79 \\
\hline $\begin{array}{l}\text { The change of shift report I } \\
\text { receive on my patients helps } \\
\text { me do my job well }\end{array}$ & & & 0.63 \\
\hline
\end{tabular}

Note: Only loadings of absolute value $>0.30$ are shown.

An item asking nurses whether they enjoyed talking with other nurses in the unit loaded on both open communication and shift report subscales domains. Because of the higher loading on the open communication subscale ( 0.62 vs 0.44 ), the item was assigned to this subscale. Counts and percentages of responses for each item, average scale, and subscale scores, corrected correlations between items and total scale, and between items and subscales, are presented in Table 3. Internal consistency was adequate in the MICU Shift Report Communication Scale sample. Cronbach's alpha for the entire instrument was estimated at 0.79. Cronbach's alpha coefficients for the communication openness, quality of information, and shift report subscales were estimated at $0.85,0.56$, and 0.79 , respectively. The items in which participants reported the highest agreement were "It is easy for me to talk openly with nurses in the MICU" (mean $[\mathrm{M}]=1.63 ; \mathrm{SD}=0.54$ ) and "It is easy to ask advice from nurses on this unit" $(\mathrm{M}=1.70 ; \mathrm{SD}=0.56)$. For items inversely scored, participants reported highest agreement with "I feel that certain nurses do not completely understand the information they receive" $(\mathrm{M}=2.76 ; \mathrm{SD}=0.73)$ and "It is often necessary 
Table 3 Descriptive statistics for the item responses, subscales, and total Medical Intensive Care Unit (MICU) Shift Report Communication Scale $(n=43)$

\begin{tabular}{|c|c|c|c|c|c|c|c|}
\hline \multirow{3}{*}{$\begin{array}{l}\text { MICU Shift Report Communication } \\
\text { subscale or item }\end{array}$} & \multicolumn{4}{|c|}{ Item responses $(n=43)$} & \multirow[t]{3}{*}{ Mean score } & \multirow{2}{*}{\multicolumn{2}{|c|}{$\begin{array}{l}\text { Corrected } \\
\text { correlations }\end{array}$}} \\
\hline & \multirow{2}{*}{$\begin{array}{l}\text { Strongly } \\
\text { agree } \\
\text { n (\%) }\end{array}$} & \multirow{2}{*}{$\begin{array}{l}\text { Agree } \\
\text { n (\%) }\end{array}$} & \multirow{2}{*}{$\begin{array}{l}\text { Disagree } \\
\text { n (\%) }\end{array}$} & \multirow{2}{*}{$\begin{array}{l}\text { Strongly } \\
\text { disagree } \\
\mathrm{n}(\%)\end{array}$} & & & \\
\hline & & & & & & Subscale & Total \\
\hline Open communication & & & & & $7.10(1.83)$ & & \\
\hline $\begin{array}{l}\text { I find it enjoyable to talk with other nurses } \\
\text { on this unit }\end{array}$ & $14(32.6)$ & $27(62.8)$ & $2(4.7)$ & & $1.72(0.55)$ & 0.71 & 0.69 \\
\hline $\begin{array}{l}\text { It is easy to ask advice from nurses on this } \\
\text { unit }\end{array}$ & $15(34.9)$ & $26(60.5)$ & $2(4.7)$ & & $1.70(0.56)$ & 0.62 & 0.65 \\
\hline $\begin{array}{l}\text { It is easy for me to talk openly with nurses } \\
\text { in the MICU }\end{array}$ & $17(39.5)$ & $25(58.1)$ & I (2.3) & & $1.63(0.54)$ & 0.42 & 0.26 \\
\hline Communication between nurses is very open & $7(16.3)$ & $27(62.8)$ & $9(20.9)$ & & $2.05(0.62)$ & 0.48 & 0.64 \\
\hline Quality of information exchanged & & & & & $5.21(1.22)$ & & \\
\hline $\begin{array}{l}\text { The accuracy of information passed among } \\
\text { nurses on this unit leaves much to be } \\
\text { desired }^{\text {a }}\end{array}$ & $4(9.3)$ & $14(32.6)$ & $23(53.5)$ & $2(4.7)$ & $2.45(0.74)$ & 0.39 & 0.21 \\
\hline $\begin{array}{l}\text { I feel that certain nurses do not completely } \\
\text { understand the information they receive } \mathrm{a}^{\mathrm{a}, \mathrm{b}}\end{array}$ & $6(14.3)$ & $21(50.0)$ & $14(33.3)$ & I (2.4) & $2.76(0.73)$ & 0.39 & 0.22 \\
\hline Shift report & & & & & $8.19(1.81)$ & & \\
\hline $\begin{array}{l}\text { The change of shift report I receive prepares } \\
\text { me to care for my patient }\end{array}$ & $7(16.3)$ & $31(72.1)$ & $5(11.6)$ & & $1.95(0.58)$ & 0.52 & 0.46 \\
\hline $\begin{array}{l}\text { It is often necessary for me to go back } \\
\text { and check the accuracy of information }\end{array}$ & $2(4.7)$ & $22(5 \mid .2)$ & I8 (4I.9) & I (2.3) & $2.58(0.63)$ & 0.39 & 0.47 \\
\hline $\begin{array}{l}\text { The change of shift report I receive } \\
\text { on my patients helps me do my job well }\end{array}$ & $8(18.6)$ & $29(67.4)$ & $6(14.0)$ & & $1.95(0.58)$ & 0.54 & 0.64 \\
\hline Total MICU Shift Report & & & & & $18.75(3.28)$ & & \\
\hline Communication Scale & & & & & & & \\
\hline
\end{tabular}

Notes: Possible range $=9-36$; lower scores indicate a more favorable perception of communication among nurses in an MICU. ${ }^{a} \mathrm{An}$ item that was scored in reverse; ${ }^{b}$ not all nurses answered this item $(n=42)$.

for me to go back and check the accuracy of information" $(\mathrm{M}=2.58 ; \mathrm{SD}=0.63)$. MICU Shift Report Communication Scale scores ranged from 12 to $27(\mathrm{M}=18.79 ; \mathrm{SD}=3.28)$. Overall MICU Shift Report Communication Scale subscale and total scores did not vary by length of work experience $(t=-1.70 ; P=0.14)$ or age $(t=-1.95 ; P=0.06)$ (Table 4).

\section{Discussion}

The MICU Shift Report Communication Scale was developed to measure nurses' perception of the quality and quantity of

Table 4 Group differences in Medical Intensive Care Unit (MICU) Shift Report Communication Scale scores

\begin{tabular}{llllll}
\hline Group & $\mathbf{n}$ & $\mathbf{M}$ & SD & $\boldsymbol{t}$ & $\boldsymbol{P}$ \\
\hline $\begin{array}{l}\text { MICU nursing } \\
\text { experience }(\mathbf{n}=\mathbf{4 2})\end{array}$ & & & & & \\
$\geq 1$ year & 30 & 19.27 & 3.41 & -1.70 & 0.14 \\
$<1$ year & 12 & 17.58 & 2.68 & & \\
Age $(\mathbf{n}=\mathbf{4 I})$ & & & & & \\
$\geq 30$ years & 21 & 17.91 & 3.22 & -1.95 & 0.06 \\
$<30$ years & 17 & 19.88 & 3.14 & & \\
\hline
\end{tabular}

Abbreviations: $M$, mean; SD, standard deviation; $t$, $t$-test. communication between nurses in the MICU. The initial try-out suggests the MICU Shift Report Communication Scale is reliable and easy to use. Findings from this study also provide further insight into nurses' perception of the quality and quantity of communication within the MICU and variations between nurses based on age and work experience.

Effective communication has been identified as an essential component of high-quality health care; ${ }^{2}$ conversely, miscommunication has been identified as the leading cause of human error in intensive care units. ${ }^{31}$ Communication during shift report involves a sender (the person providing information and releasing care) and a receiver (the person accepting information and assuming responsibility for care). ${ }^{3}$ The goal of effective communication in health care is to get both the sender and the receiver "watching the same movie with no surprises." However, over one-third of the nurses participating in this study reported dissatisfaction with the accuracy of information exchanged during shift report. Further, over half felt that "certain nurses do not completely understand the information they receive." Using the MICU Shift Report Communication Scale to examine nurses' perception on the 
quality and quantity of information will provide insight into the effectiveness of current shift report processes. The MICU Shift Report Communication Scale could also be used by nursing leaders to evaluate the effectiveness of initiatives to improve communication.

The quality and quantity of communication during shift report is greatly influenced by the knowledge and experience of the nurses giving and receiving patient report. ${ }^{32}$ Almost one-third of the nurses participating in this study had worked in the MICU and health care for $<1$ year. This is important because Ebright et $\mathrm{al}^{33}$ found that novice nurses have specifically identified handoff communication as stressful and a contributing factor to patient errors, especially when the handoff report occurs with other novice nurses. While many stressors influence novice turnover, ${ }^{34-36}$ it is likely that poor communication within the clinical environment influences the decision of many to leave their first nursing role within 1 year of graduation. ${ }^{37}$ Examining the impact of structured tools on novice nurse communication during shift report may provide insight into effective interventions to facilitate socialization into and greater satisfaction with the nursing role.

Throughout their educational preparation and subsequent career, nurses are instructed on methods to communicate effectively (eg, therapeutic communication and conflict management). As a result, it was not surprising that nurses participating in this study had a favorable perception of the openness of communication within the MICU. However, the problem with communication specific to ensuring the transfer of comprehensive patient information is that, while it is relatively easy to talk about accomplishing this goal, it is seldom easy to achieve in practice. ${ }^{38}$ Reflecting on this challenge, nurses in this study were far less satisfied with the quality of information exchanged and communication during shift report.

\section{Limitations}

The MICU Shift Report Communication Scale is a new instrument that requires further psychometric testing and factor analysis with larger samples in diverse intensive care settings to determine if the subscales accurately represent the domains of communication during shift report. One item, "I find it enjoyable to talk with other nurses on this unit" loaded on two subscales (open communication and shift report). Future examination of this item with a larger sample of nurses is needed to determine item usefulness as a measure of nurse communication. As with any instrument using self-report, the MICU Shift Report Communication Scale is subject to social desirability bias. Participants may answer questions as they think they should rather than respond from their own communication experiences. However, this is unlikely as the need to improve shift report communication was identified by staff nurses within the MICU. We attempted to minimize this risk by ensuring potential participants that all responses would be completely de-identified. Based on the initial psychometric evaluation, the MICU Shift Report Communication Scale demonstrated acceptable validity and reliability; however, additional research is needed to further test and identify opportunities to improve the instrument.

\section{Conclusion and implications for future studies}

This article has reported the initial item development and administration of the MICU Shift Report Communication Scale. Continued development with larger and more diverse groups of intensive care unit nurses will further establish the psychometric properties and item functioning of the scale. Although the use of standardized communication tools to guide a structured shift report are believed to be effective, there is little empiric evidence to support the use of any one specific structure, protocol, or method. ${ }^{39}$ Utilization of the MICU Shift Report Communication Scale to examine the nurse perception of the effectiveness of standardized tools to improve the quality and quantity of communication will provide empiric evidence to either support or refute the use of standardized tools or interventions. Simulation of the MICU Communication Tool ${ }^{24}$ using the MICU Shift Report Communication Scale to evaluate pre- and post-training will reflect gaps in handoff communication for actual practice. ${ }^{40}$ Finally, examining the impact of standardized tools on nurses' perception of the quality and quantity of communication and workforce outcomes, such as work satisfaction, turnover rate, and intent to leave, may allow health care leaders to develop and implement effective standardization communication tools.

\section{Disclosure}

The authors declare no conflicts of interest in this work.

\section{References}

1. Ong MS, Coiera E. A systematic review of failures in handoff communication during intrahospital transfers. Jt Comm J Qual Patient Saf. 2011;37(6):274-284.

2. Leonard M, Graham S, Bonacum D. The human factor: the critical importance of effective teamwork and communication in providing safe care. Qual Saf Health Care. 2004;13 Suppl 1:i85-i90.

3. Blouin AS. Improving hand-off communications: new solutions for nurses. J Nurs Care Qual. 2011;26(2):97-100.

4. Kerr MP. A qualitative study of shift handover practice and function from a socio-technical perspective. J Adv Nurs. 2002;37(2):125-134. 
5. Triplett $P$, Schuveiller C. Nurses' end-of-shift report process and implementation of a standardized report format tool and bedside handoff. Critical Care Nurse. 2011;31(2):e43-e44.

6. Gibson SC, Ham JJ, Apker J, Mallak LA, Johnson NA. Communication, communication, communication: te art of the handoff. Ann Emerg Med. 2010;55(2):181-183.

7. Hughes RG, Clancy CM. Improving the complex nature of care transitions. J Nurs Care Qual. 2007;22(4):289-292.

8. Riesenberg LA, Leisch J, Cunningham JM. Nursing handoffs: a systematic review of the literature. Am J Nurs. 2010;110(4):24-34; quiz $35-26$.

9. Streitenberger K, Breen-Reid K, Harris C. Handoffs in care - can we make them safer? Pediatr Clin North Am. 2006;53(6):1185-1195.

10. Health care worker fatigue and patient safety. Sentinel Event Alert. 2011;48:1-4.

11. The Joint Commission. Hand-off communications. 2011. Available from: http://www.centerfortransforminghealthcare.org/projects/detail. aspx?project=1. Accessed January 24, 2013.

12. Cohen MD, Hilligoss PB. The published literature on handoffs in hospitals: deficiencies identified in an extensive review. Qual Saf Health Care. 2010;19(6):493-497.

13. The Joint Commission. Joint Commission Center for Transforming Healthcare announces handoff communications solutions. 2010. Avail-

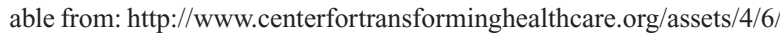
CTH_Hand-off_commun_set_final_2010.pdf. Accessed January 24, 2013.

14. Owen C, Hemmings L, Brown T. Lost in translation: maximizing handover effectiveness between paramedics and receiving staff in the emergency department. Emerg Med Australas. 2009;21(2):102-107.

15. Dingley C, Daugherty K, Derieg MK, Persing R. Improving patient safety through provider communication strategy enhancements. In: Henriksen K, Battles JB, Keyes MA, Grady ML, editors. Advances in Patient Safety: New Directions and Alternative Approaches. Vol. 3: Performance and Tools. Rockville, MD: US Agency for Healthcare Research and Quality; 2008. 1-12.

16. Rabol LI, Andersen ML, Ostergaard D, Bjorn B, Lilja B, Mogensen T. Republished error management: Descriptions of verbal communication errors between staff. An analysis of 84 root cause analysis-reports from Danish hospitals. Postgrad Med J. 2011;87(1033):783-789.

17. Thorne SE, Bultz BD, Baile WF. Is there a cost to poor communication in cancer care? A critical review of the literature. Psychooncology. 2005;14(10):875-884; discussion 885-876.

18. The Joint Commission. Standard outlines handoff process. Healthcare Benchmarks and Quality Improvement. 2011; March, 1.

19. Agarwal R, Sands DZ, Diaz-Schneider J. Quantifying the economic impact of communication inefficiencies in US hospitals. Decision, Operations, and Information Technologies. 2008;3(1B):1-4.

20. Haig KM, Sutton S, Whittington J. SBAR: a shared mental model for improving communication between clinicians. Jt Comm J Qual Patient Saf. 2006;32(3):167-175.

21. Braun BD. Evaluating and improving the handoff process. $J$ Emerg Nurs. 2012;38(2):151-155.

22. Perry SJ, Wears RL, Patterson ES. High-hanging fruit: improving transitions in health care. In: Henriksen K, Battles JB, Keyes MA, Grady ML, editors. Advances in Patient Safety: New Directions and Alternative Approaches. Vol. 3: Performance and Tools. Rockville, MD: US Agency for Healthcare Research and Quality; 2008. 1-9.

Nursing: Research and Reviews

\section{Publish your work in this journal}

Nursing: Research and Reviews is an international, peer-reviewed, open access journal publishing original research, reports, reviews and commentaries on all aspects of nursing and patient care. These include patient education and counselling, ethics, management and organizational issues, diagnostics and prescribing, economics and
23. Dartmouth Microsystem Academy. Clinical microsystems [website on the Internet]. Dartmouth: Trustees of Dartmouth College; nd. Available from: http://www.clinicalmicrosystem.org/. Accessed January 24, 2013.

24. Jukkala AM, James D, Autrey P, Azuero A, Miltner R. Developing a standardized tool to improve nurse communication during shift report. J Nurs Care Qual. 2012;27(3):240-246.

25. Dougherty MB, Larson EL. The Nurse-Nurse Collaboration Scale. J Nurs Adm. 2010;40(1):17-25.

26. Ushiro R. Nurse-Physician Collaboration Scale: development and psychometric testing. J Adv Nurs. 2009;65(7):1497-1508.

27. Hojat M, Fields SK, Veloski JJ, Griffiths M, Cohen MJ, Plumb JD. Psychometric properties of an attitude scale measuring physician-nurse collaboration. Eval Health Prof. 1999;22(2):208-220.

28. Weiss SJ, Davis HP. Validity and reliability of the Collaborative Practice Scales. Nurs Res. 1985;34(5):299-305.

29. Shortell SM, Rousseau DM, Gillies RR, Devers KJ, Simons TL. Organizational assessment in intensive care units (ICUs): construct development, reliability, and validity of the ICU nurse-physician questionnaire. Med Care. 1991;29(8):709-726.

30. Gliem JA, Glien RR. Calculating, interpreting, and reporting Cronbach's alpha reliability coefficient for Likert-type scales. Paper presented at the 2003 Midwest Research-to-Practice Conference, Adult, Continuing, and Community Education, Ohio State University, Columbus, Ohio. 2003. Oct 8-10. Available from: http://scholarworks.iupui.edu/ handle/1805/344. Accessed January 24, 2013.

31. Donchin Y, Gopher D, Olin M, et al. A look into the nature and causes of human errors in the intensive care unit. Crit Care Med. 1995;23(2): 294-300.

32. Friesen MA, White SV, Byers JF. Handoffs: implications for nurses. In: Hughes RG, editor. Patient Safety and Quality: An Evidence-Based Handbook for Nurses. Rockville, MD: US Agency for Healthcare Research and Quality; 2008. 1-48.

33. Ebright PR, Urden L, Patterson E, Chalko B. Themes surrounding novice nurse near-miss and adverse-event situations. J Nurs Adm. 2004; 34(11):531-538.

34. Suzuki E, Itomine I, Kanoya Y, Katsuki T, Horii S, Sato C. Factors affecting rapid turnover of novice nurses in university hospitals. JOccup Health. 2006;48(1):49-61.

35. Duchscher JB, Myrick F. The prevailing winds of oppression: understanding the new graduate experience in acute care. Nurs Forum. 2008; 43(4):191-206.

36. Laschinger HK, Finegan J, Wilk P. New graduate burnout: the impact of professional practice environment, workplace civility, and empowerment. Nurs Econ. 2009;27(6):377-383.

37. Bowles C, Candela L. First job experiences of recent RN graduates: improving the work environment. J Nurs Adm. 2005;35(3):130-137.

38. Seago JA. Professional communication. In: Hughes RG, editor. Patient Safety and Quality: An Evidence-Based Handbook for Nurses. Rockville, MD: US Agency for Healthcare Research and Quality; 2008. 1-26.

39. PattersonES. Communication strategies from high-reliability organizations: translation is hard work. Ann Surg. 2007;245(2):170-172.

40. Berkenstadt H, Haviv Y, Tuval A, et al. Improving handoff communications in critical care: utilizing simulation-based training toward process improvement in managing patient risk. Chest. 2008;134(1): $158-162$.

resource management, health outcomes, and improving patient safety in all settings. The manuscript management system is completely online and includes a very quick and fair peer-review system. Visit $\mathrm{http} / / / \mathrm{www}$.dovepress.com/testimonials.php to read real quotes from published authors. 